JeMAS 13 (2) (2017) 152-157
Jttp://journal.unnes.ac.id/nju/index.php/kemas

\title{
THE EFFECT OF DISPOSABLE WATER (DIAPER) USAGE TOWARD TOILET TRAINING BEHAVIOR IN PRE-SCHOOL CHILDREN
}

\author{
Munjiati, Aris Fitriyani ${ }^{\bowtie}$, Walin \\ Purwokerto Nursing Program Study, Poltekkes Kemenkes Semarang
}

\section{Article Info}

Article History:

Submitted September 2016

Accepted November 2017

Published November 2017

\section{Keywords:}

Diaper, Toilet Train-

ing, Pre-School Children

\section{DOI}

http://dx.doi.org/10.15294/

kemas.v13i2.7242

\begin{abstract}
Diaper is an option for most mothers because they are practical for the parents and make babies sleep better. Children who wear diapers often show late toileting development since they cannot feel a sense of damp when urinating. This study aimed to know the use of baby diapers on toilet training behavior of pre-school children in Early Childhood Education Programs (PAUD) and Kindergarten at Mersi village, Purwokerto. This was a non-experimental quantitative study with cross-sectional study design. The population was 217 children with history of diaper usage. The samples were 68 respondents who met the inclusion criteria. The data was analyzed using Chi Square. This research has already been conducted in 2013 . The results showed that $85.4 \%$ respondents wore diapers, whereas $14.6 \%$ did not. $12.5 \%$ respondents had good toilet training behavior, $78 \%$ had sufficient behavior $78 \%$, and $9.5 \%$ were lacking. There was a significant difference between history of diapers usage and toilet training behavior among pre-school children in Early Childhood Education Programs (PAUD) and Kindergarten at Mersi village $(p=0,04)$. It can be concluded that there was a significant difference between the usage of baby diapers and toilet training behaviors in pre-school children.
\end{abstract}

\section{Introduction}

Toilet training behavior is one of toddler's actions to recognize bladder and bowel activity. Toddler should be able to recognize the sensation of releasing and detaining elimination and able to communicate the sensation of bladder and bowel emptying to parents (Alexandra, 2008; Klijn, 2006). At toddler stage, children face a conflict between the parents' demands and their desire and physical capabilities. Parents want children to control their bladder and bowel activity and release at the proper place, whereas children want to release the urge as soon as the sensation to urinate/defecate appears (Chung, 2007; Carol, 2009). Toilet training in children is an attempt to train children the way to control urination and defecation habits. Toilet training can generally be carried out when the child has entered the self-reliance phase (Keen, 2007; Wald, 2009). This phase usually occurs in children aged 18-24 months. Children need physical, psychological and intellectual preparation to start toilet training. From those preparations, the child would learn to control defecation and urination independently.

Toilet training would be successful if there is a cooperation between the parent and child. Good cooperation will foster mutual trust between parents and their children. According to some studies, child's attitudes, behaviors and

\footnotetext{
Correspondence Address:

pISSN 1858-1196

Jl. Mersi Purwokerto

eISSN 2355-3596

Email : aris.fitriyani@yahoo.co.id
} 
ways of thinking later as an adult would be greatly influenced by his experience at this time. Toilet training is very important in shaping the children's character and establishes mutual trust in parent-child relationship. Failure of parents to implement toilet training could cause the child to be stubborn and difficult to manage. In addition, the child will not be independent and retain the habit of bed-wetting until the end of childhood. Teaching toilet training would be more difficult for parents as the children grow older (Hidayat in Setyowati 2013).

Toilet training or urination and defecation exercise is a child development task of toddler because at this age the ability to control defecation starts to grow (Indanah, 2014). According to Mufattahah (in Soebagyo, 2010), although it is not easy, parents must remain motivated to stimulate their children to get used to urinate or defecate at the proper time and place. Child's social skills and self-reliance development could be stimulated by toilet training, in which parents teach their children to tell them whenever they need to urinate or has a bowel movement, and accompany the child when urinating or defecating and tell them how to clean themselves and flush the toilet.

Soebagyo (2010) mentioned that factors affecting the success of toilet training includes, firstly, physical readiness (aged 18- 24 months, can sit or squat for about 2 hours, have regular bowel movements, achieved gross motor skills such as sitting, walking and fine motor skills such as undressing). Secondly, mental readiness (recongnizing urinating and defecating sensation that emerge suddenly, verbal and nonverbal communication when needing to urinate and defecate, cognitive skills to follow orders and imitate the behavior of others). Thirdly, the psychological readiness (sitting or squatting on the toilet for 5-10 minutes without getting up, curiosity on the adults' habits in defecation, feeling uncomfortable with the damp sensation or presence of solids in the diapers, and wanting diapers to be replaced soon). Fourthly, readiness of parents (to know the child's level of readiness to urinate and defecate, desire to spend the time necessary for the child's urination and defecation exercise, and not in conflict or family stress, for example, divorce).

Teaching toilet training in children takes time and patience, hence some parents choose to use diapers to simplify their job (Febrida in Indanah 2014). Putting children in diaper is one way to reduce mothers' job in cleaning the child after each urination or defecation. Diaper is disposable cloth made of plastic and chemical mixture with high absorptive capability to contain urine and feces. The effects of diapers usage are increased humidity on areas in contact with diaper and the presence of friction between diaper and the skin, resulting in increased vulnerability to skin irritation (Wong, 2009).

$\mathrm{Hu}$ Y (2004) revealed that children used to wearing diapers instead of cloth diapers will have different toilet ability. Children who wear diapers will have slower toileting development since they can not feel the damp sensation when urinating. Parents who use diapers on their usually only look from the practicality and convenience standpoint only, although using diaper too often may cause skin irritation and the child will not be accustomed to go to the toilet to urinate (Indanah, 2014). Children who are accostumed to wear diaper from baby until five years old or older will show some differences from other children such as difficulty to control the urge to urinate or defecate, not telling their parents when they want to urinate or defecate, feeling lazy to go to the bathroom, and their attitude tend to be careless and stubborn (Fleisher, 2008).

Based on the data obtained by researchers, East Purwokerto sub-district has a large population and $1 / 4$ of that population is made up of pre-school children. The phenomenon that commonly occurs in the community is usage of diapers for children since less than 1 year old and even since birth. The usual reason expressed by the parents is practicality, because they do not need to frequently change the diapers whenever the child urinates.

This research must be done to determine the success rate of toilet training among preschool children who have went through toddler stage and to determine the effect of diaper usage on the children's toilet training behavior. When such problems are not adequately addressed, it is possible that the diaper usage by 
parents would increase in frequency, resulting in the increase of incontinentia cases above the expected age of toilet training and then this mentality would continue until the children pass their developmental age tasks. Based on the introduction above, the researchers were interested to study the "The Effect of Disposable Water (Diaper) Usage towards Toilet Training Behavior among Pre-School Children".

Methods

This research was a quantitative study with cross sectional approach. This method was used to determine the relationship between history of diaper usage on toilet training behavior among pre-school children. This research was conducted from June to August 2013.

The population in this study was children aged 3-6 years old, totaling 217 children and all parents of children at Mersi Village Early Childhood Education Program and Kindergarten. The sampling technique was purposive sampling. The sample were 68 children and 68 parents that matches the inclusion criteria which were children aged 3-6 years and enrolled in Mersi Village Early Childhood Education Program and Kindergarten, mothers consented to her child participation in this study, able to read, write and communicate verbally and non-verbally.

Data was collected by questionnaires on children's toilet training behavior, history of diapers usage, and respondents' characteristics data such as the child's sex, age, education and parents' occupation (mother), and history of diaper usage, the child's physical, intellectual and psychological readiness in toilet tranining and parents' readiness in supporting successful toilet training. Its validity and reliability was tested using Pearson product moment.

The data obtained was analyzed using univariate and bivariate analysis through a computer program. Univariate analysis was carried out on the gender of the child, the child's age, education level and parents' occupation (mother), frequency of diapers usage, readiness of children and parents in the child's toilet training success variables, whereas in bivariate analysis chi square analysis was used (Nursalam, 2014).

Results and Discussion
The research conducted on students of Mersi Village Early Childhood Education Program and Kindergarten showed that from all 68 respondents, female students outnumbered the male students with $68.1 \%$ to $31.9 \%$ ratio. The respondents consisted of aged 3 - $<3.5$ year $(10.3 \%), 3.5$ - aged $<4$ years $(8.7 \%)$, aged $4-<4.5$ years $(43.5 \%), 4.5$ - aged $<5$ years $(27.5 \%)$, aged $5-<5.5$ years $(8.2 \%)$ and aged 5,5-6 years (1.8\%). Based on a survey conducted in Indonesia, at the age of 5 years, approximately $20 \%$ of children will experience enuresis once a month; $5 \%$ of boys and $1 \%$ of girls will do it at night. At the age of 6 years, the percentage of children with enuresis decreases $10 \%$ and most of them are boys (Jumeisetyo (2008) in Kusbiantoro, 2012).

Failure to control the urination process could cause enuresis. Enuresis is a disorder in micturition that cannot be controlled at daytime and nighttime, in children aged four years old and older, without any physical disorder or organic disease (Kroeger 2010 in Musfiroh \& Wisudaningtyas, 2014). In a four-year old children, the bladder's external sphincter can already be controlled, but the child cannot control their micturition. One of the cause is failure of toilet training. When such condition persist for a long time would disrupt children's development tasks. The success of toilet training is not only affected by physical, psychological and emotional capability of the children, but also by the behavior of parents or mothers to teach toilet training well and properly, so that the child can do it well until they grew older (Warner, 2007; Barone 2009 in Musfiroh, 2014).

Perent's education background in this study was classified into elementary school, $6.8 \%$, junior high school, $19.9 \%$, senior high school, $63.4 \%$ and unversity, $9.9 \%$. The higher the education level, the higher the knowledge, skills and positive role of parents, and vice versa. Education also influences parents' capability to accept information provided by others. Parents with low education and knowledge may have little insight, therefore they are unaware of the impact of constantly using disposable diaper on successful toilet training and they think that putting disposable diaper would facilitate their work in taking care of the children (Kusbiantoro, 2012). This is because 
the majority (63.4\%) of parents ended their education at senior high school. This result was in line to Henik's (2013) study which examined mother's knowledge about toilet training and toilet training behavior. The study showed that the higher the mother's knowledge, the child's toilet training behavior would be better. The results of this study were in accordance to the research proposed by Lestari (2013) which stated that mother's knowledge about good toilet training influences the frequency of diapers usage, which means that the frequency of diapers usage might be one of the factor that influence ability of toilet training. Elfita's research (2015) on mother's knowledge and attitude about toilet training for children aged 1-3 years revealed that mothers with 2 or more children had better knowledge and attitude than mothers with only 1 child.

The parents' occupation in this study were $4.5 \%$ laborer, $64,5 \%$ housewife, $5.2 \%$ civil servant, $20,4 \%$ private employee and $5.4 \%$ entrepreneur. The majority of parent's occupation from respondents in early childhood education programs (PAUD) and Mersi's village kindergarten was housewives, hence the access to information was very limited. Children's toilet training is influenced by internal and external factors. The internal factors are readiness and motivation of children, whereas the external factors is the mother's role as caregiver. Mother's occupation is related to the flexibility of mother in conducting toilet training training for the child, the more time mothers have for training, the toilet training ability of the child would increase. This study showed that most of them were housewives, so their flexibility to care their children was sufficiently high. There is a relationship between parents' role and the toilet training capability of children as shown in Heriyanto's study (2010) which concluded that parents' role influence the implementation of toilet training in toddlers; the higher the role of parent, the better the capability of toilet training in the child.

Based on the results of study conducted in early childhood education programs (PAUD) and Village Mersi's kindergarten showed that the percentage of diaper usage was $85.4 \%$, while the frequency of respondents who did not use diapers was $14.6 \%$. The frequency of diapers usage was in accordance to Indanah's study (2014) which showed that most respondents (34 respondents/71\%) applied diaper to their children only when traveling. In the group of mothers who applied diaper only when traveling resulted in good toilet ability of the child (56\%). In the group of mothers who applied diapers daily on their child, their child's toilet ability was poor. Based on the duration of diaper usage and toilet training ability of the child, this study results showed that the group of mothers who changed diapers every $\leq 3$ hours had children with good toilet ability (87\%), there was a significant relationship between frequency of diaper usage and toilet training ability in toddler, with a value of 7,600 and $p$ value $=0.020(p<0.05)$, hence the frequency of diaper usage in children can affect toilet training ability in toddler age. The result of this study was in accordance to the study conducted by Istichomah (2009), which found that the mother's activity affected duration of diaper usage. Therefore, the mother did not pay attention about the timing to replace her child's diaper until the child was restless, cried, and the diaper was dirty. Hence, the longer the mother replaces the diapers, the harder it would be to achieve toilet training ability in the child.

The result on the children's physical readiness for toilet training showed that the percentage of children with good toilet training behavior was $12.5 \%$, the frequency of children with sufficient toilet training behavior was $80.2 \%$, and $7.3 \%$ had poor toilet training behavior. From the aspect of children's intellectual readiness for toilet training, the percentage of children with good toilet training behavior was $86.3 \%$, while $13.7 \%$ had poor toilet training behavior. From the aspect of psychological readiness, the frequency of children with good psychological readiness and good toilet training behavior was $37.3 \%$ and $47.3 \%$ children was not ready psychologically, while the frequency of children with poor psychological readiness and toilet training behavior was $15.4 \%$. From the aspect of parental readiness in supporting toilet training behavior of their children showed that the percentage of children with good toilet training behavior was $85.3 \%$, while the frequency of children with poor toilet training behavior was $14.7 \%$. According 
to Soebagyo (2010), parents' readiness for toilet training is to recognize the child's readiness level for urination and defecation, the desire to spend the time required for urination exercise and defecation for their children.

The chi-square test was performed to find out the relationship between diaper usage and toilet training behavior in pre-school age children in PAUD and Village Mersi's kindergarten, which showed that children who had used diaper and had good toilet training behavior was $4.8 \%, 82.9 \%$ was sufficient, while $10.7 \%$ children had poor toilet training behavior. The children who had not used diaper and had good toilet training behavior was $16.1 \%, 77.4 \%$ was sufficicient and $6.5 \%$ was poor. From the analysis of history of diaper usage and toilet training behavior, the $p$ value was 0,04 , and $p<\alpha(0,05)$, thus it can be said that there was a correlation between history of diaper usage and toilet training behavior in pre-school children in PAUD Village Mersi's kindergarten. Besides, high attitude scores do not automatically guarantee appropriate actions to that behavior. This was in accordance to the theory in social psychology as mentioned by Wald (2009). Wald (2009), mentioned experts had differing opinions about the relationship between attitude and behavior. Social support, knowledge, attitudes, and selfefficacy are variables that potentially influence action (Ichsan, 2015). In the author's language, the behavior referred to was the act of parents in using diapers does not necessarily bring success in children's toilet training. Attention from closest people, such as mothers can not be denied, even pregnant women has been getting supportive information from their parents. In addition, the husband is the mother's partner who has a major contribution to successful toilet training in their children (Wibowo, 2016).

The relationship between diaper usage and toilet training behavior at preschool age, including the aspect of children's physical readiness, intellectual readiness, psychological readiness and parental readiness, obtained a significance value of $\mathrm{p}=0.04(\mathrm{p}<0.05)$. This means that there was a relationship between the usage of diaper and toilet training behavior in preschool children at PAUD and Mersi's village kindergarten. This was in accordance to Indanah's (2014) study on diapers usage and effects on toilet capabilities in toddler-aged. This study concluded that there was a relationship between diapers usage with toileting ability in toddler aged, where the longer use of diapers hence lowering toilet ability of the child. The results of this study also supported by Nining's study (2013) which examined the influence of parenting and the intensity of diapers usage to the level of readiness of toilet training in toddler age. The study also concluded that intensity of diaper usage affected children's toilet training readiness, where children who used diapers with high intensity (routine) had lower level of readiness for toilet training than children who used diapers with irregular intensity. Children with habitual usage of diapers from infants to toddler age would have different experience from other children. The differences are the child's difficulty to control desire to urinate or defecate, the child does not tell his parents when they want to urinate or defecate, lazy to go to the bathroom, and the child's attitude tend to be careless or stubborn (Fleisher, 2008).

\section{Conclusions}

There was a relationship between history of disposable diaper usage and toilet training behavior of pre-school children at early childhood education (PAUD) and Village Mersi's kindergarten. Besides, history of diapers usage during toddler age can affect toilet training behavior of pre-school children. Therefore, mothers should start to introduce toilet training at the age of 12 months. Thus, when the child reaches the age of 36 months, they chould be ready for good toileting behavior.

\section{Acknowledgments}

Acknowledments to: parents/ guardians of the students at early childhood education programs (PAUD) and Village Mersi's kindergarten who were willing to be respondents in this study, Nursing Programs of Purwokerto Poltekkes Kemenkes Semarang.

\section{References}

Alexandra, V. 2008. Toilet training of healthy young toddlers: a randomized trial between a daytime wetting alarm and timed potty training. Journal of Developmental \& Behavioral Pediatrics, 29(3): 191- 196.

Barone, Joseph G. 2009. Later toilet training is associated with urge incontinence in children. Journal of Pediatric Urology, 5(6): 458-461. 
Carol, Joinson. 2009. A prospective study of sge at initiation of toilet training and subsequent daytime bladder control in school-age children. Journal of Developmental \& Behavioral Pediatrics, 30(5): 385-39.

Chung, Kyong-Mee. 2007. Modified Version of Azrin and Foxx's Rapid Toilet Training. Journal of Developmental and Physical Disabilities, 19(5): 449-455.

Elfita, S. 2015. Gambaran pengetahuan dan sikap ibu tentang pelaksanaan toilet training pada anak usia 1-3 tahun di wilayah kerja Posyandu Desa Kubang Jaya Kabupaten Kampar. Jurnal Kesehatan, 2 (2).

Fleisher, D. 2008. Heterogenity of diapers dependency in three six year-old children: implication for management. Journal of Nursing. Columbia: University of Missouri School of Medicine.

Henik, I. 2013. Perilaku ibu tentang toilet training pada anak usia 1-3 tahun di Desa Kajoran Kecamatan Klaten Selatan Kabupaten Klaten. Jurnal STIKES Telogorejo, 1 (2).

Heriyanto, B. 2010. Pengaruh peran keluarga terhadap pelaksanaan toilet training pada anak toddler di pos PAUD terpadu Harapan Bangsa Wonokromo Surabaya. Jurnal Kesehatan, 2 (1).

$\mathrm{Hu}$ Y, Beach J, Raymer J and Gardner, M. 2004. Disposable diaper to collect urine samples from young children for pyrethroid pesticide studies. Journal of Exposure Analysis and Environmental Epidemiology, 14 : 378-384.

Ichsan, B., Salimo, H., \& Soebijanto, H.A.A. 2015. Keefektifan program kelompok pendukung ibu dalam mengubah prilaku ibu menyusui, Jurnal KEMAS, 10 (2) : 186-194

Indanah. 2014. Pemakaian diapers dan efek terhadap kemampuan toilet training pada anak usia toddler. Jurnal Ilmu Keperawatan, 5 (3)

Istichomah. 2009. Hubungan tingkat pengetahuan ibu asuh dengan pelaksanaan toilet training di TPA Citra RSU Rajawali Citra Bantul. Jurnal Kesehatan Surya Medika Yogyakarta

Keen, Deb. 2007. Toilet Training for Children with Autism: The Effects of Video Modeling. Journal of Developmental and Physical Disabilities, 19(4): 291-303.

Klijn, Aart J. 2006. Home Uroflowmetry Biofeedback in Behavioral Training for Dysfunctional Voiding in School-Age Children: A Randomized Controlled Study. The Journal of Urology, 175(6): 2263-2268.

Kroeger, K. 2010. A parent training model for toilet training children with autism. Journal of In tellectual Disability Research, 54(6):556567.

Kusbiantoro, D. (2012). Keberhasilan toilet training pada anak usia 3-4 tahun berhubungan dengan pemakaian disposable diaper. Jurnal Ilmiah Ilmu-Ilmu Kesehatan, 10 (1).

Lestari, A \& Supriyono. 2013. Hubungan antara tingkat pengetahuan ibu tentang toilet training dengan praktik ibu dalam penggunaan diapers pada anak usia toddler (1-3 tahun) di Kelurahan Putat Purwodadi. Jurnal STIKES Telogorejo, 1 (2).

Musfiroh, M \& Wisudaningtyas, B.L. 2014. Penyuluhan terhadap sikap ibu dalam memberikan toilet training pada anak. Jurnal KEMAS, 9 (2) : 157-166.

Nining, F. 2013. Pengaruh pola asuh orang tua dan intensitas penggunaan diapers terhadap tingkat kesiapan toilet training pada anak usia toddler di Little Care Stikes Surya Global Yogyakarta. Publikasi Thesis. Surakarta: Program Pasca Kedokteran Fakultas Kedokteran Universitas Sebelas Maret.

Nursalam. 2014. Metodologi penelitian ilmu keperawatan : Pendekatan praktis edisi 3, Salemba Medika, Jakarta.

Soebagyo, dkk. 2010. Hubungan antara motivasi stimulasi toilet training oleh ibu dengan keberhasilan toilet training pada anak pra sekolah. Jurnal Penelitian Kesehatan Suara Forikes, 1 (2)

Setyowati, P.Y., \& Kasanah, U. 2013. Hubungan pola asuh orang tua dengan tingkat keberhasilan toilet training pada anak Balita (4-5 Tahun) di Dusun Kernekan Desa Tunggak Kecamatan Toroh Kabupaten Grobogan Tahun 2012. Jurnal Ilmu Kebidanan dan Kesehatan (Journal of Midwifery Science and Health), 3 (2) : 51-56.

Wald, E.R. 2009. Bowel habits and toilet training in a diverse population of children. Journal of Pediatric Gastroenterology \& Nutrition, 48(3): 294-298.

Warner, P. \& Kelly, P. 2007. Mengajari Anak Pergi Ke Toilet. Alih Bahasa Valentina Hadiwibowo. Jakarta : Arcan.

Wibowo, M. 2016. Dukungan informasi bagi ibu menyusui dalam memberikan asi eksklusif di Kecamatan Gondokusuman, Yogyakarta. Jurnal KEMAS, 11 (2) (2016) 97-103.

Wong, L. (2009). Buku ajar keperawatan pediatrik Vol. 1. Alih Bahasa: Agus Sutarna. Jakarta. 